\title{
Developing a Spiritual Well-Being Training Module to Increase Tolerance
}

\author{
Raja Oloan Tumanggor ${ }^{1 *}$ Heni Mularsih $^{1}$ \\ ${ }^{1}$ Faculty of Psychology, Universitas Tarumanagara, Jakarta, Indonesia \\ "Corresponding author. Email: rajat@fpsi.untar.ac.id
}

\begin{abstract}
This research develops a module for spiritual well-being training to increase tolerance. The aim is that this module can be used as training material to build tolerance for individuals and groups. In addition, this study also aims to implement modules so that they are easy to understand in supporting the implementation of spiritual well-being training. This study uses a qualitative method. The result of the development of this module is training materials which consist of first, exposing some of the phenomena of intolerance in Indonesia. Then in the second part, the reasons and motivation for someone to be intolerant are discussed, especially from a psychological perspective. Third, what effective strategies can be done to overcome this intolerant behavior. Of the many possibilities, it turns out that the results of the study show that improving spiritual well-being plays a role in developing a person's tolerance. Therefore it is necessary to describe the meaning and spiritual dimension of well-being, as well as its relation to tolerance. The fourth material discusses what efforts can be made to improve spiritual well-being, so that tolerance can develop well.
\end{abstract}

\section{Keywords: spiritual well-being, training module, tolerance}

\section{INTRODUCTION}

Attitude is a term that reflects the feeling of whether you are happy or not happy with something or someone. According to Sarwono [1], there are three aspects in attitude, namely affect, behavior, and cognition. Affect is a feeling that arises whether happy or unhappy. Behavior is behavior that follows those feelings either approaching or avoiding, and cognition is an assessment of the object of attitude. Therefore attitude is a person's feelings, thoughts and tendencies which are more or less permanent regarding certain aspects of their environment. Attitude components can be in the form of knowledge, feeling, and the tendency to act. In other words, attitude is an evaluative tendency towards an object or subject that has consequences, namely how a person deals with the object of the attitude.

Meanwhile, tolerance is a generous attitude towards other people's principles. This does not mean sacrificing the principles he adheres to, but remains strong in principles that are reflected in a firm attitude to follow his beliefs. Tolerance is the ability to withstand things that are not approved in order to build better social relations. Tolerance implies acceptance and respect for the views, beliefs, and values of other groups that are different from us. Meanwhile, intolerance is the unwillingness to respect and accept differences. [2]

So from the description above it can be understood that tolerance means being willing to accept the diversity and trust that other parties / groups believe. This recognition is not only on the equality of degrees in the state and society structure, but also on differences in how to live and perform worship [3]. Tolerance is a person's awareness to respect, respect, tolerate, and allow their stand, views, beliefs, beliefs, and provide space for the implementation of other people's religious habits, behaviors and practices that are different or contrary to one's own stand in order to build a life together and relationships social better [4]. With tolerance, the unity and integrity of the nation will be preserved. Development can be pursued and continued, so that gaps can be minimized. Relations between religious communities are based on the principle of good brotherhood, working together to face enemies and defend those who are suffering [5].

However, in reality this attitude of tolerance is increasingly tarnished by the behavior of a group of intolerant people in the midst of society. Various violations of freedom of religion and expression (KBB) and expressions of intolerance have shown an increase in intensity at least in the past years. Since the 2019 national political year, there has been an increasing trend in expressions of intolerance and discrimination against minority religious groups [6].

In cases of intolerance, this often involves teenagers. Adolescents are a group of people who are struggling to find their identity and at the same time become a determining group in the progress of future generations. A nation will progress if its youth receive adequate assistance. However, in the current situation, teenagers become perpetrators of intolerance due to the influence of their environment. Intolerance cases are a serious problem 
and can have negative consequences for adolescents if not resolved immediately [7].

Many factors make teenagers fall into intolerant actions in society. Social media makes it easy for teenagers to obtain information from radical views. It is not uncommon for teenagers to be easy targets for extreme organizations that spread radical ideologies that threaten pluralism in Indonesia. Information about radicalism easily reaches teenagers. In addition, adolescents who do not receive adequate spiritual guidance from religious institutions and their families will be increasingly vulnerable to various negative influences including intolerance.

To fortify adolescents from intolerance, it is necessary to pay attention to the spiritual aspect of well-being. Spiritual well-being is an affirmation of living in a relationship with God, self, community and the environment [8]. Spiritual Well-Being is an indication of a person's quality of life in the spiritual dimension or an indication of his spiritual health [9]. According to J.W. Fisher [10] in spiritual wellbeing, every human individual is built a relationship with himself, others, the environment and God. This relationship is then developed in four interconnected domains. The four domains include the first, the personal domain, where a person relates to himself regarding the meaning, purpose and values in life. This awareness is the determining force of the human spirit in seeking selfidentity. Second, the communal domain appears in the quality and depth of interpersonal relationships between oneself and others, related to morality, culture and religion. This relationship is expressed in love, forgiveness, trust, hope and faith. Third, the environmental domain concerns physical and biological maintenance, a sense of belonging and awe and the idea of oneness with the environment. Fourth, the transcendental domain includes the relationship between oneself and something that transcends the human aspect, such as peak concern, cosmic forces and transcendent reality [11].

From the results of research conducted on 1113 junior high and high school students in 5 provinces (DKI, West Java, Central Java, Lampung, and North Sumatra), it was found that there was a significant relationship between spiritual well-being and tolerance, and the higher the level of welfare. spiritual, the better the tolerance attitude of youth [12]. This means that spiritual well-being is the basis for a person in building tolerance towards others. On that basis, in this second year research, a spiritual well-being training module was developed to build tolerance for adolescents. The aim is that through spiritual well-being training, youth can build and improve their tolerance towards others.

\section{METHOD}

This training module development research uses a qualitative approach and action research/action research in formulating an intervention model to help increase tolerance for adolescents. According to Greenwood and Levin [13] action research has three important elements. First, action to state an action aimed at transforming a certain group or organization into a more liberating condition. This act of liberation can be interpreted in various ways. The meaning that is in line with this research is liberation through increasing self-awareness of adolescents. By achieving an attitude of tolerance they are expected to see themselves more positively, not as people who are defeated by intolerant groups. Second, the research element, namely the effort to achieve a more liberating condition is achieved through a series of studies. Third, participation. Participants or participants in training (adolescents) are involved as fellow researchers. Researchers work with participants to define the problems that occur, formulate solutions, implement these solutions, then reflect back on the actions that have been taken.

In the process of preparing this training module, the researcher referred to the research and development model compiled by Borg \& Gall [14]. Of the 10 steps in the development of the Borg \& Gall model, the researcher summarizes them into five steps, namely: (1) the preproduct development stage, which is collecting information about module needs by conducting a literature study on spiritual well-being and tolerance, as well as field observations, (2) the product development stage, namely planning by doing the learning design and writing training modules, (3) the trial stage, namely conducting trials in small groups in the field, (4) the revising stage, namely making improvements in accordance with the suggestions of the activity testing and implementing training modules in the field, (5) the implementation stage, namely conducting product dissemination and application.

\section{RESULTS}

\section{Module Development}

In the first year of research it has been found that there is a relationship between spiritual well-being and attitudes of torelance. The higher a person's spiritual well-being, the higher his tolerance will be [15]. Starting from this fact, a spiritual well-being training module was developed as an effort to build tolerance which is described in the following four sub-modules.

Recognizing the phenomenon of intolerance (Module 1) This section describes several cases of intolerance that have occurred in Indonesia. The threat of intolerance has become a real thing in society. Judging from the place and time of the incident, incidents of intolerance have occurred in almost every region of Indonesia, and they are occurring more and more frequently. The impact was felt both materially and psychologically because the victim was traumatized and unable to perform worship and was unable to practice his faith freely.

\section{Causes of intolerance: a psychological perspective (Module 2)}

After witnessing various cases of intolerance from material I the question arises: Why do people easily become intolerant? Much research and discussion has been conducted to address this question. There is a feeling of being threatened: from whom? From people who are not of 
their own religion/ethnicity. There is suspicion of adherents of other religions: What is suspicion? The feeling that adherents of other religions will destroy their own faith and beliefs. Having a high level of religious / ethnic fanaticism: assuming that his religion and tribe are the best and greatest. According to the Nusantara Task Force (Satgas) [16] there are three reasons for someone to become intolerant: (1) Globalization which erodes eastern values, eg tolerance; (2) Democracy which is dominated by low class: groups. this is easily influenced to make changes quickly and instantaneously and is irrational; (3) The development of social media (medsos) is very fast so that radical understanding can spread quickly.

In the world of developmental psychology, the debate behind the formation of behavior always leads to two big concepts, namely whether behavior is influenced by nature or nature or behavior is shaped by the process of learning and experience (nurture). Research Amanda Ramos, a developmental psychology researcher from Penn State University, United States (US), tries to bridge these two concepts with its research. According to him, genetic factors give humans inner potential. However, it is undeniable that environmental factors play a role in shaping the behavior of each individual. The difference between religious beliefs and concepts that are seen as truth is certainly getting wider in the midst of an increasingly complex society.

Whereas people live not only based on one culture or religion alone, but also live side by side with other communities who have different cultures or religions. This condition causes conflicts to be prone to occur and lead to intolerant behavior. Friction between groups of people who have different beliefs and values is prone to causing intolerant behavior. This is a phenomenon that often occurs in groups of people who have a very high level of religious fundamentalism. They believe that their religion is the most correct compared to other religions. A deeply ingrained identity will build motivation to fight for their religion. This causes individuals willing and courageous to volunteer themselves to fight on behalf of the group to do extreme activities.

\section{Solutions to overcome intolerance through spiritual well-being (Module 3)}

The plight of intolerance must be dealt with properly. The way to overcome this is by providing provision to teenagers so that later they are not involved in intolerant acts in society. Provisioning in the form of training must be encouraged from now on considering that teenagers have the potential to become intolerant actors in their homes. If they do not have the correct concept of diversity, young people are vulnerable to engaging in acts of intolerance. Teenagers can become actors who support or sympathize with intolerant groups.

Why do spiritual welfare improvements need to be done to overcome the problem of intolerance? What does spiritual well-being have to do with intolerance? Before answering this question, it is necessary to first explain what spiritual well-being is. Improving spiritual well-being is a solution to overcome intolerance. What is meant by spiritual well- being, what are the dimensions of spiritual well-being, and what is the relationship between spiritual well-being and tolerance? Gomez and Fisher state that spiritual well-being is a state that reflects positive feelings, behaviors and cognitions from relationships with oneself and others, as well as relationships with the Almighty (transcedent) and nature, which ultimately gives individuals a sense of identity, wholeness, satisfaction, joy, beauty, love, respect, positive attitude, inner peace and harmony, and purpose and direction of life [17].

Dimensions of spiritual well-being include: (1) Relationship with oneself (personal domain), relating to oneself, the search for personal meaning, the search for life goals and values. This personal domain is related to selfawareness, which is the driving force of the human soul to achieve identity and self-worth, its aspects: meaning, purpose, values, self-awareness, joy, peace, patience, identity and self-worth. (2) Relationships with others (communal domain) in the form of interpersonal qualities and abilities with a deeper level of quality, building relationships with other people, related to morality and culture. The existence of love, forgiveness, trust, hope and the ability to actualize faith in others, its aspects: moral, culture, religion, depth of interpersonal relationships, forgiveness, justice, love and trust. (3) Relationship with the environment (environmental domain), in the form of natural attachment to the environment, satisfaction during peak experiences, enjoying natural beauty, the ability to maintain the environment in order to benefit the surroundings, aspects: caring, work (taking care of ), a connection with nature, and a peak of awe-inspiring experience. (4) Relationship with transcendent (transcendental domain), the ability to establish a relationship with a creator, involving faith, worship and worship of the transcendent reality, namely God. There is an aspect of faith (faith) in God: a very transcendent interest, a natural force that refers to a sense that transcends time and space, very worry, belief, worship, and worship [18].

After exploring the understanding and spiritual dimension of well-being, we want to see how it relates to tolerance. However, before looking at the relationship, it is worth explaining what is meant by tolerance. In the beginning of this training, several phenomena of intolerance that occur in Indonesia have been witnessed and what factors make people intolerant. So to understand what tolerance is, of course all aspects are contrary to and contrary to intolerance.

Tolerance or tolerant in language this word comes from the Latin tolerare which means to patiently let something. The broad definition of tolerance is a human behavior or attitude that does not deviate from the rules, where someone respects or appreciates every action taken by others (wikipedia.com). Tolerance can also mean an attitude of mutual respect and respect between groups or between individuals (individuals) both within society and in other spheres. An attitude of tolerance can avoid discrimination, even though there are many different groups or groups in a community group. Tolerance occurs 
because of the desire to avoid disputes that are mutually harmful to both parties.

According to UNESCO tolerance is an appreciation, acceptance, and appreciation of the differences in world culture, and the different forms of expression and human existence. Tolerance is harmony in difference [19]. Agus Supriyanto \& Amien Wahyudi [20] which refers to Diane Tillman's idea reveal several characteristics or characters of tolerance including (a) peace as a goal, (b) openness and receptive to differences, (c) respect for each other, (d) avoiding fear and indifference, (e) having the seeds of love, (f) appreciating the good in others, (g) accepting life's inconveniences by leaving others with their quirks. Then the aspects of tolerance character can be summarized in the following table

Table 1 Aspects of the character of tolerance [21]

\begin{tabular}{|c|c|c|}
\hline & Tolerance aspect & Tolerance indicator \\
\hline 1 & Peace & $\begin{array}{l}\text { Care } \\
\text { No fear } \\
\text { Love }\end{array}$ \\
\hline 2 & $\begin{array}{l}\text { Respect differences } \\
\text { and individuals }\end{array}$ & $\begin{array}{l}\text { Respect each other } \\
\text { Respect other people's } \\
\text { differences } \\
\text { Respect your self }\end{array}$ \\
\hline 3 & Awareness & $\begin{array}{l}\text { Appreciate the kindness of } \\
\text { others } \\
\text { Open } \\
\text { Receptive } \\
\text { Comfort in life } \\
\text { Convenience with other } \\
\text { people }\end{array}$ \\
\hline
\end{tabular}

There are many benefits that can be obtained if the characters mentioned above can be implemented properly, including: (a) Strengthening nationalism: Tolerance can show how much a person's sense of nationalism. Because people who have high tolerance, usually will have a high sense of love for their homeland. Because he realized that Indonesia is a plural country that has many differences. (b) Strengthening brotherhood: Indonesia consists of various islands. It also consists of various regions with different cultures. With an attitude of tolerance, everyone respects each other and gives equal affection for every difference. (c) Creating harmony and peace: The linguistically meaning of tolerance means restraint. That is a sign, everyone who has a sense of tolerance can refrain from imposing personal opinions on others. So that harmony will be maintained, because they can understand each other. That way, peace will also follow.

From the results of empirical research it has been shown that there is a significant relationship between spiritual well-being and tolerance. Some of the researchers who have analyzed it are as follows: MD Walker [22] concluded that there is a relationship between tolerance and spiritual maturity. If a person is more spiritually mature then he is more tolerant, than spiritually less mature person. Philip Hughes [23] examined the relationship between spirituality and tolerance. Quoting a study from the International social source program (2008), Hughes underlines that people who claim to be spiritual are more tolerant than those who claim to be religious. In some countries spirituality is not always associated with belief in God, but has a fairly high religious tolerance. Karina Schumann [24] spirituality makes people more tolerant. Schumann and his team concluded that when a person remembers their spiritual beliefs they tend to have feelings of tolerance and less hostility. Tumanggor \& Mularsih [25] argue that the higher a person's spiritual well-being, the better his tolerance will be.

\section{Strengthening tolerance through improving spiritual well-being (Module 4)}

Has spiritual well-being builds tolerance? Why can a spiritually prosperous person have an attitude of tolerance? Do we have to have spiritual well-being to have an attitude of tolerance? The answer is JA. By having spiritual wellbeing, a person can be more tolerant, because if someone has a good relationship with oneself, others, the environment and God, it will be easier for him to (1) accept and appreciate differences because he has a good relationship with oneself. 2) respecting other people to worship because they have a good relationship with God, (3) being a good listener, because they have good relationships with others, (4) Do not force their will, because they have a good relationship with themselves, (5) ) able to speak politely because they have a good relationship with the universe.

Various attitudes that can be taken to increase tolerance are (1) accepting and respecting differences, (2) not gossiping, (3) being a good listener, (4) speaking politely, (5) allowing others to worship, (6) Don't force your will. To build spiritual well-being can be expressed in various ways as shown in the following table.

Table 2 How to build spiritual well-being [26]

\begin{tabular}{lllll}
\hline \multicolumn{5}{c}{ Dimensions of spiritual well-being } \\
\hline & personal & $\begin{array}{l}\text { communa } \\
l\end{array}$ & $\begin{array}{l}\text { environm } \\
\text { ental }\end{array}$ & $\begin{array}{l}\text { Trancend } \\
\text { ental }\end{array}$ \\
\hline $\begin{array}{l}\text { Knowl } \\
\text { edge } \\
\text { aspect }\end{array}$ & $\begin{array}{l}\text { Meaning, } \\
\text { purpose, } \\
\text { values }\end{array}$ & Morality & $\begin{array}{l}\text { Care, } \\
\text { nurture }\end{array}$ & $\begin{array}{l}\text { Ultimate } \\
\text { concern, }\end{array}$ \\
\hline Essenc & Awarenes & $\begin{array}{l}\text { Reaching } \\
\text { the heart } \\
\text { e }\end{array}$ & $\begin{array}{l}\text { Connecte } \\
\text { dness }\end{array}$ & God \\
& $\mathrm{s}$ & $\begin{array}{l}\text { of } \\
\text { humanity } \\
\text { creature }\end{array}$ & \\
\hline $\begin{array}{l}\text { Expres } \\
\text { sed as }\end{array}$ & $\begin{array}{l}\text { Joy, } \\
\text { peace, } \\
\text { freedom, } \\
\text { humility, }\end{array}$ & $\begin{array}{l}\text { Love, } \\
\text { forgivene } \\
\text { ss, justice }\end{array}$ & $\begin{array}{l}\text { Valueing } \\
\text { nature }\end{array}$ & $\begin{array}{l}\text { Adoratio } \\
\text { n, }\end{array}$ \\
& wdentity & & & worship \\
\end{tabular}

Since when did we do all that? Starting early in the family. Parents teach their children to love themselves, others, nature and God. The role of parents is important in 
educating children so that they can have a good relationship with themselves, others, the environment and God. In the following video [27] you can see how a child gets to know another person who has a different culture and religion than him. Good habits that have been instilled in a person from childhood will continue to carry over until he is an adult / old. In other videos such as the following [28] reveals the experience of a poor father who can share even though he is in need. A good attitude to share with others will get good rewards not only from God, but also from others.

Who are we? We are all Indonesians of various ethnicities, cultures and religions. We are born different in the same homeland. So let's be aware of this diversity as revealed by this short video entitled We Are Indonesia [29] What can we do to improve spiritual well-being? The main step is to fix good relationships with oneself, with others, with the natural environment, and with God (The Transcendent). We are fixing good relations with these four quadrants in the context of Indonesia's diversity. Can it be? Yes, you can. We can all do this when there is one thing in our hearts, which is love. With love we will be able to relate to anyone: ourselves, others, the environment and God as expressed by this beautiful song from the BIP band group [30].

After conducting the training, it is followed by the preparation of a follow-up plan and evaluation. The follow-up plan aims to encourage participants not only to do the tasks of the facilitator, but also to be able to make work stages, target groups and outputs to be produced. So after this training, especially regarding the importance of strengthening tolerance through improving spiritual welfare, it is necessary to formulate what participants should do.

As a first step, there are several tasks that need to be done by participants so that the training material can be effectively understood not only at the cognitive level, but also at the affective and psychomotor level. The tasks are as follows (1) Write down what you can do to build good relationships with yourself, others, the universe / environment, and God! (2) Look for an object that is a symbol of tolerance, then take a photo of the object, and explain why the object becomes / describes an attitude of tolerance? Or (2) Draw a picture or painting depicting an attitude of tolerance in our social life! Or (2) Make a poster inviting young people to always show tolerance.

After delivering all the training materials to the participants, of course an evaluation material is needed to determine the effectiveness of using this module to increase tolerance for adolescents. One method that can be used is to use research instruments including questionnaires, observation sheets, and tolerance test questions. The observation sheet is used to observe the training results from an affective and psychomotor perspective. The test question is used to determine the increase in the tolerance attitude of adolescents in the cognitive domain. The data analysis technique used the One Group Pretest-Posttest Design. According to Sugiyono (2011)[31], the effectiveness test design uses the One Group Pretest-Posttest Design with one class using a training module by giving a pretest at the beginning of the training and a posttest at the end of the training. Then tested using the T-Test (Paired Samples T-Test) which is used to test the difference in the average of more than two samples with the assumption that the population is normally distributed, the data variation is the same, but the samples are not related to one another, and is calculated with $\mathrm{N}$-gain. normalized. The normality of the gain score is a technical analysis to determine the level of increase in tolerance from before using the training module and after using the training module to increase tolerance.

\section{CONCLUSION}

This research succeeded in developing a spiritual wellbeing training module in building tolerance for adolescents. The training material is divided into four major parts, first is to be aware of the phenomenon of intolerance that occurs in Indonesia, which aims to open the awareness of training participants to the situation of intolerance. The second part explores the psychological basis of why people can become intolerant and what factors influence it. Then the third part discusses solutions that can be done to build tolerance through spiritual wellbeing, because tolerance is closely related to the condition of one's relationship with oneself, others, the environment and God. So the strategy taken to build an attitude of tolerance is to improve spiritual well-being, which is the fourth topic of discussion, strengthening tolerance through spiritual well-being. In the implementation stage of the training module the facilitator must adapt the training material to the conditions of the participants. This means that not all stages and materials in the module can be carried out during the training through the zoom application. Some parts of the material must be simplified. It is recommended that the implementation of this module be carried out directly through face-to-face meetings, so that the emotional relationship between the facilitator and the training participants can be built. Therefore, the process of building tolerance through improving the spiritual welfare of the participants can be more effective.

\section{ACKNOWLEDGMENT}

We would like to thank the Ministry of Research, Technology and Higher Education / National Research and Innovation Agency (Kemenristek Dikti / BRIN) for funding this research for the 2020 fiscal year. We also thank the Directorate of Research and Community Service (DPPM) Tarumanagara University Jakarta which has facilitated us to do this research.

\section{REFERENCES}

[1] Sarwono, J.W. (2010). Psikologi Remaja, Raja Grafindo, Jakarta. 
[2] Khisbiyah, Y. (2007). Menepis prasangka, memupuk toleransi untuk multikulturalisme: Dukungan dari psikologi sosial. Surakarta: PSB-PS UMS.

[3] Bahari (ed.). (2010). Toleransi beragama mahasiswa: Studi tentang pengaruh kepribadian, keterlibatan organisasi, hasil belajar Pendidikan agama, dan lingkungan Pendidikan terhadap toleransi mahasiswa berbeda agama pada 7 perguruan tinggi umum negeri (cet.1) Kementerian Agama RI, Badan Litbang dan Diklat, Puslitbang Kehidupan Keagamaan.

[4] Ghufron, M.N. (2016). Peran Kecerdasan Emosi dalam meningkatkan toleransi beragama. FIKRAH, 4 (1), 138.

[5] Ghufron, M.N. (2016). Peran Kecerdasan Emosi dalam meningkatkan toleransi beragama. FIKRAH, 4 (1), 138.

[6] Press release of Setara Institute 16 November 2020

[7] Supriyanto, A. \& Wahyudi, A. (2017). Skala Karakter Toleransi: Konsep dan Operasional Aspek Kedamaian, Menghargai Perbedaan dan Kesadaran Individu, Jurnal Ilmiah Counsellia, Vol. 7 (2), 61-70.

[8] Fisher, J.W. (2011). The Four Domains Model: Connecting Spirituality, Health and Well-Being. Religions 2, 17-28.

[9] Ellison, C.W. (1983). Spiritual Well-being: Conceptualization and measurement. Journal of Psychology and Theology, 11 (4), 330-340; Bufford, R.K., Paloutzian, R. F., Ellison, C.W. (1991). Norms for the Spiritual Well-being Scale. Journal of Psychology and Theology 19 (1), 56-70.

[10] Fisher, J.W. (2011). The Four Domains Model: Connecting Spirituality, Health and Well-Being. Religions 2, 17-28.

[11] Fisher, J.W. (2011). The Four Domains Model: Connecting Spirituality, Health and Well-Being. Religions 2, 17-28; Fisher, J.W., \& Ng, D. (2017) Presenting a 4-Item Spiritual Well-Being Index (4ISWBI). Religions 8, 179.

[12] Tumanggor, R.O. \& Mularsih, H. (2020). Relationship of Spiritual Well-Being and Attitudes of Tolerance. CELL EAI DOI: 10.4108/eai.5-82019.2291041

[13] Greenwood, D.J. and Levin, M. (2007) Introduction to action research Social research for social change. Sage Publications, Thousand Oaks.
[14] Borg, W.R., \& Gall, M.D. (2007). Education research: an Introduction, $8^{\text {th }}$ ed., Utah State University, Pearson.

[15] Tumanggor, R.O. \& Mularsih, H. (2020). Relationship of Spiritual Well-Being and Attitudes of Tolerance. CELL EAI DOI: 10.4108/eai.5-82019.2291041

[16] Kompas.com, 11/15/2019.

[17] Gomez, R., \& Fisher, J. W. (2005). The spiritual well-being questionnaire: Testing for model applicability, measurement and structural equivalencies, and latent mean differences across gender. Personality and Individual Differences, 39(8), 13831393. https://doi.org/10.1016/j.paid.2005.03.023

[18] Fisher, J.W., \& Ng, D. (2017) Presenting a 4-Item Spiritual Well-Being Index (4-ISWBI). Religions 8, 179.

[19] Hjerm, M.; Eger, M.A.; Bohman, A.; Connolly, F.F. (2020). A New Approach to the Study of Tolerance: Conceptualizing and Measuring Acceptance, Respect, and Appreciation of Difference. Social Indicators Research 147:897-919 https://doi.org/10.1007/s11205-019-02176-y

[20] Supriyanto, A. \& Wahyudi, A. (2017). Skala Karakter Toleransi: Konsep dan Operasional Aspek Kedamaian, Menghargai Perbedaan dan Kesadaran Individu, Jurnal Ilmiah Counsellia, Vol. 7 (2), 61-70.

[21] Supriyanto, A. \& Wahyudi, A. (2017). Skala Karakter Toleransi: Konsep dan Operasional Aspek Kedamaian, Menghargai Perbedaan dan Kesadaran Individu, Jurnal Ilmiah Counsellia, Vol. 7 (2), 61-70.

[22] Walker, M.D., (2011), "Religious Tolerance and its Relationship to Spiritual Maturity and Religious Orientation Among Seventh-day Adventists in Jamaica". Dissertations.1523. http://digitalcommons andrews.edu/dissertations/1523

[23] Hughes, P. (2013). Spirituality and Religious Tolerance. Implicit Religion 16 (1), 65-91.

[24] Schumann, K., McGregor, I., Nash, K. A., \& Ross, M. (2014). Religious magnanimity: Reminding people of their religious belief system reduces hostility after threat. Journal of Personality and Social Psychology, 107(3), 432-453. https://doi.org/10.1037/a0036739

[25] Tumanggor, R.O. \& Mularsih, H. (2020). Relationship of Spiritual Well-Being and Attitudes of 
Tolerance. CELL EAI DOI: 10.4108/eai.5-8-2019. 2291041

[26] Fisher, J.W. (2011). The Four Domains Model: Connecting Spirituality, Health and Well-Being. Religions 2, 17-28.

[27] https://www.youtube.com/watch?v=Ndud9fmGX WE

[28] https://www.youtube.com/watch?v=WhjtnNaDn08 $\& \mathrm{t}=77 \mathrm{~s}$

[29] https://www.youtube.com/watch?v=TIKbhfaBrvs

[30] https://www.youtube.com/watch?v=HyXgxwmnWM

[31] Sugiyono. (2011). Metodologi Penelitian Kuantitatif, Kualitatif, dan R\&D. Bandung: Alfabet. 